\title{
Germination behaviour of seeds from herbicide treated plants of Chenopodium album $\mathrm{L}$.
}

\author{
ASIF TANVEER, MUHAMMAD A. NADEEM, ASGHAR ALI, \\ MUHAMMAD TAHIR and MUHAMMAD S. I. ZAMIR \\ Department of Agronomy, University of Agriculture, Faisalabad, Pakistan 38040 \\ Manuscript received on July 26, 2007; accepted for publication on August 2, 2009; \\ presented by ELIBIO L. RECH
}

\begin{abstract}
The carry-over effect of sub-lethal herbicides was investigated on the germination of seeds collected from surviving Chenopodium album plants, which had received 1/8, 1/8 twice, 1/8 three times, 1/4, 1/2, 1/1 doses of either preemergence ioxynil or post-emergence bentazone in a previous onion (Allium cepa) crop. Seeds were also collected from surviving $C$. album plants, which had received 1/4, 1/2, 1/1 of either pre-emergence pendimethalin, propachlor and linuron, or 1/8, 1/8 twice, $1 / 8$ three times, $1 / 4,1 / 2,1 / 1$ of post-emergence ioxynil or linuron in a previous leek (Allium porrum) crop. Seeds of surviving plants were collected and tested for germination at temperature of 5, 10, 15, 20 and $25^{\circ} \mathrm{C}$. The effect of different temperatures on the total number of germinated seeds was significant. Germination was minimum at low temperatures $\left(5^{\circ} \mathrm{C}\right.$ or $\left.10^{\circ} \mathrm{C}\right)$. Herbicides did not show any effect on germination of C. album and resulted in the same final germination percentage as seeds collected from the unsprayed control plots.
\end{abstract}

Key words: herbicides, sub-lethal doses, onion, leek, germination.

\section{INTRODUCTION}

Chenopodium album is an annual Chenopodiaceae and a common weed in plant communities (Bassett and Crompton 1978) and soil seedbanks (Forcella et al. 1992) of many cropping systems. Peak germination (Baskin and Baskin 1977) of C. album usually occurs in early to mid-spring. It can tolerate a temperature ranging from $5-30^{\circ} \mathrm{C}$ and is better adapted to temperate zones and in tropics (Holm et al. 1977). This species has become serious in spring vegetables production areas of U.K., especially in onion and leek crops. The success of $C$. album as a competitive weed species is attributed to many factors, including seed germination in a wide range of environmental conditions (Henson 1970) and early emergence during the crop growing season (Ogg and Dawson 1984).

Correspondence to: Dr. Asif Tanveer

E-mail: drasiftanveeruaf@hotmail.com
There are advices for using pendimethalin, ioxynil, propachlor and bentazone in C. album control in vegetables. Farmers are using application rates lower than the originally recommended ones, which may have effects on the subsequent germination of C. album seeds derived from herbicide treated weeds. It may be reflected in the success of future weed germination and changes the rate of input to the persistent seedbank. In such a situation more information is needed on the relationship between C. album germination and sub-lethal herbicide applications to the previous generation. This is because variation in seed traits may be determined not only by the genotype and environment of that individual, but also by maternal effects. This will result in maternal carry-over effects if seeds are used next time (Baskin and Baskin 1973). Although much has been published on germination of C. album at various temperatures, very little has been written about the germination of seed progeny collected from herbicide treated weeds. 
Fawcett and Slife (1978) found that viability of C. album, Amaranthus retoflexus L., Datura stramonium L. and Setaria feberi Herrum seeds produced by 2, 4-D and dalapon treated plants was not greatly different from control seeds. Reduced germination or viability due to herbicide application has also been reported by Singhal and Sen (1981), Doliner and Stewart (1992), Young et al. (1984), Kasera and Sen (1986), Catizone and Viggaiani (1990) and Don et al. (1990). In contrast, Hume and Shirriff (1989) reported an increase in germination in seeds from herbicide-treated plants.

Kintner and Aldrich (1984) applied sublevel rates of chlorsulfuron to Abutilon theopbrati Meidc. at flower bud formation and found that seed germination was reduced. However, chlorsulfuron applied post.em. at $140 \mathrm{~g} \mathrm{ha}^{-1}$ to Secale cereale L. did not affect seed viability or germination (Zollinger and Evans 1985). Henzell et al. (1985) reported that soil - applied atrazine at sub-lethal rates reduced the germination of Arabidopsis thathiana (L.) Heynh (mouseear cress). Conversely, chlorsulfuron did not affect the mouseear cress seed.

Glyphosate and chlorsulfuron reduced seed germination of $A$. theopbrasti when applied at different stages of weed growth (Biniak and Aldrich 1986). Frank and Ralph (1987) reported a reduction of $64 \%$ in germination of Salsola iberica seed from plants treated with chlorsulfuron at 17.05 and $26 \mathrm{~g} \mathrm{ha}^{-1}$ and paraquat at $560 \mathrm{~g} \mathrm{ha}^{-1}$. Isaacs et al. (1989) stated that the use of chlorimuron and imazaquim at $0.28 \mathrm{~kg} \mathrm{ha}^{-1}$ in Cassia obtusifolia at early bloom and early fruit stages produced seeds incapable of emergence. Reduction in the germination of Galium spurium L. and Thlaspi arvense L. by subnormal doses of tribenuron-methyl (1/8, 1/4 and 1/2 of normal field dose) was reported by Andersson (1994). Germination was also reduced in Fallopia convolvulus by Methyl Chloro phenoxy Acetic acid (MCPA). Zhang and Cavers (1994) reported a significant reduction in the viability of seeds after maternal bentazone application to Xanthium strumarium L.

Shuma et al. (1995) reported that glyphosate at $0.44,0.88$ and $1.76 \mathrm{~kg}$ ai ha ${ }^{-1}$ applied 5 and 10 days after anthesis (DAA) significantly suppressed germination of Avena fatua seed with $1.76 \mathrm{~kg}^{\text {ai }} \mathrm{ha}^{-1}$ being the most effective rate. When applied to plants 15 DAA, only the highest rate significantly affected the overall germi- nation. Andersson (1996) in a pot trial with plants of three broad-leaved species at five growth stages and two herbicides at four dosages, found varying effects on seed germination. Hald (1999) noted that T. arvense L. and Sinapis arvensis L. seeds from unsprayed controls had a high germination rate, but the proportion of seeds germinating was highest at low dosage (1/16) of isoproturon.

The aim of the present study was to investigate the germination behaviour of seeds of herbicide treated C. album under different temperatures and, importantly, to examine whether there are any correlations with the different herbicides and their rates in the previous generation.

\section{MATERIALS AND METHODS}

\section{Plant MATERIAL}

Seeds of C. album for this experiment were collected from plants that had survived after spraying onion ( $A l$ lium cepa) and leek (Allium porrum) crops infested with a natural weed flora at Horticulture Research International, Wellesbourne, UK in 2002.

Chenopodium album seed was cleaned to remove the husk and other debris and was stored dry in tightly closed plastic bags at $4^{\circ} \mathrm{C}$ until the start of germination tests. The onion crop had been sprayed with preemergence bentazone and post- emergence ioxynil (see Table I for details of rates and application dates). Full rate for bentazon and ioxynil was $3 \mathrm{~L} \mathrm{ha}^{-1}$ and $2.8 \mathrm{~L} \mathrm{ha}^{-1}$, respectively.

The leek crop had been sprayed with pre-em pendimethalin pre-em ioxynil and pre-em. propachlor preemergence linuron, post-emergence linuron (see Table II for detailed information on rates and application dates). The full recommended rates for pendimethalin, ioxynil, propachlor linuron (pre and post) were $3.3 \mathrm{~L} \mathrm{ha}^{-1}$, 2.8 $\mathrm{L} \mathrm{ha}^{-1}, 9.0 \mathrm{~L} \mathrm{ha}^{-1}, 1.7 \mathrm{~L} \mathrm{ha}^{-1}$, respectively.

\section{SEED GERMinAtion}

Chenopodium album seed collected at harvest from both the onion and leek crops were sown at Coventry University Plant Science Department in February 2003. Fifty seeds of $C$. album from each treatment were randomly placed in $9 \mathrm{~cm}$ dia Petri dishes, lined with two Whatman discs with filter paper No. 1 at the bottom. 
TABLE I

Herbicide treatments for onion.

\begin{tabular}{c|c|c}
\hline Herbicide treatments & Application rates & Number of applications \\
\hline \multirow{4}{*}{$\begin{array}{c}\text { Ioxynil } \\
\text { (post-emergence) }\end{array}$} & Full $\left(3.00 \mathrm{~L} \mathrm{ha}^{-1}\right)$ & One \\
\cline { 2 - 3 } & Half $\left(1.50 \mathrm{~L} \mathrm{ha}^{-1}\right)$ & One \\
\cline { 2 - 3 } & Quarter $\left(0.75 \mathrm{~L} \mathrm{ha}^{-1}\right)$ & One \\
\cline { 2 - 3 } & Eighth $\left(0.375 \mathrm{~L} \mathrm{ha}^{-1}\right)$ & Two (11 days interval) \\
\cline { 2 - 3 } & Eighth $\left(0.375 \mathrm{~L} \mathrm{ha}^{-1}\right)$ & One \\
\cline { 2 - 3 } & Eighth $\left(0.375 \mathrm{~L} \mathrm{ha}^{-1}\right)$ & One \\
\hline \multirow{4}{*}{$\begin{array}{c}\text { Bentazone } \\
\text { (pre-emergence) }\end{array}$} & Full $\left(2.80 \mathrm{~L} \mathrm{ha}^{-1}\right)$ & One \\
\cline { 2 - 3 } & Half $\left(1.40 \mathrm{~L} \mathrm{ha}^{-1}\right)$ & One \\
\cline { 2 - 3 } & Quarter $\left(0.70 \mathrm{~L} \mathrm{ha}^{-1}\right)$ & Two (11 days interval $)$ \\
\cline { 2 - 3 } & Eighth $\left(0.35 \mathrm{~L} \mathrm{ha}^{-1}\right)$ & \\
\cline { 2 - 3 } & Eighth $\left(0.35 \mathrm{~L} \mathrm{ha}^{-1}\right)$ & \\
\cline { 2 - 3 } & Eighth $\left(0.35 \mathrm{~L} \mathrm{ha}^{-1}\right)$ & \\
\hline Control & None & \\
\hline Planting date & 26.6 .2002 & \\
\hline Date of 1 ${ }^{\text {st }}$ spray & 15.7 .2002 & \\
\hline
\end{tabular}

TABLE II

Herbicide treatments for leek.

\begin{tabular}{|c|c|c|}
\hline Herbicide treatments & Application rates & Number of applications \\
\hline \multirow{6}{*}{$\begin{array}{c}\text { Ioxynil } \\
\text { (post-emergence) }\end{array}$} & Full $\left(2.80 \mathrm{~L} \mathrm{ha}^{-1}\right)$ & One \\
\hline & Half (1.40 L ha-1) & One \\
\hline & Quarter $\left(0.70 \mathrm{~L} \mathrm{ha}^{-1}\right)$ & One \\
\hline & Eighth $\left(0.35 \mathrm{~L} \mathrm{ha}^{-1}\right)$ & One \\
\hline & Eighth $\left(0.35 \mathrm{~L} \mathrm{ha}^{-1}\right)$ & Two (11 days interval) \\
\hline & Eight $\left(0.35 \mathrm{~L} \mathrm{ha}^{-1}\right)$ & Three (11 days interval) \\
\hline \multirow{6}{*}{$\begin{array}{c}\text { Linuron } \\
\text { (post-emergence) }\end{array}$} & Full $\left(1.7 \mathrm{~L} \mathrm{ha}^{-1}\right)$ & One \\
\hline & Half $\left(0.85 \mathrm{~L} \mathrm{ha}^{-1}\right)$ & One \\
\hline & Quarter $\left(0.425 \mathrm{~L} \mathrm{ha}^{-1}\right)$ & One \\
\hline & Eighth $\left(0.2125 \mathrm{~L} \mathrm{ha}^{-1}\right)$ & One \\
\hline & Eighth $\left(0.2125 \mathrm{~L} \mathrm{ha}^{-1}\right)$ & Two (11 days interval) \\
\hline & Eighth $\left(0.2125 \mathrm{~L} \mathrm{ha}^{-1}\right)$ & Three (11 days interval) \\
\hline \multirow{3}{*}{$\begin{array}{c}\text { Propachlor } \\
\text { (pre-emergence) }\end{array}$} & Full $\left(9.0 \mathrm{~L} \mathrm{ha}^{-1}\right)$ & One \\
\hline & Half $\left(4.5 \mathrm{~L} \mathrm{ha}^{-1}\right)$ & One \\
\hline & Quarter $\left(2.25 \mathrm{~L} \mathrm{ha}^{-1}\right)$ & One \\
\hline \multirow{3}{*}{$\begin{array}{l}\text { Pendimenthalin } \\
\text { (pre-emergence) }\end{array}$} & Full $\left(3.3 \mathrm{~L} \mathrm{ha}^{-1}\right)$ & One \\
\hline & Half (1.65 $\left.\mathrm{L} \mathrm{ha}^{-1}\right)$ & One \\
\hline & Quarter $\left(0.825 \mathrm{~L} \mathrm{ha}^{-1}\right)$ & One \\
\hline \multirow{3}{*}{$\begin{array}{c}\text { Linuron } \\
\text { (pre-emergence) }\end{array}$} & Full $\left(1.7 \mathrm{~L} \mathrm{ha}^{-1}\right)$ & One \\
\hline & Half $\left(0.85 \mathrm{~L} \mathrm{ha}^{-1}\right)$ & One \\
\hline & Quarter $\left(0.425 \mathrm{~L} \mathrm{ha}^{-1}\right)$ & One \\
\hline Control & None & - \\
\hline Planting date & 25.06 .2002 & \\
\hline Date of $1^{\text {st }}$ spray & 15.7 .2002 & \\
\hline
\end{tabular}


$2.85 \mathrm{ml}$ of Deionized water per dish was added at the time of seed sowing using a pipette. $2.85 \mathrm{ml}$ of subsequent water per Petri dish was added when needed. Petri dishes were sealed with one-inch-dia core parafilm "M" and covered with plastic envelopes to minimize moisture loss. The germination dishes for this experiment were arranged in a completely randomized design (CRD) with four replications.

Germination was evaluated for one month at five stable temperatures of $5,10,15,20$ and $25^{\circ} \mathrm{C}$ using separate incubators. Germinated seeds from individual Petri dishes were counted and removed every day at an interval of 24 hours along one month. Germination was defined as when the radicle protruded more than $2 \mathrm{~mm}$ from the seed. All data were analysed statistically using the statistical package GENSTAT (Payne et al. 1995).

\section{RESULTS AND DISCUSSION}

GERMINATION OF C. album

AT DIFFERENT TEMPERATURES

The results obtained with seed placed at different temperatures between 5 and $25^{\circ} \mathrm{C}$ are presented in Figure 1 . There was a significant difference among the different temperatures regarding germination of $C$. album seed collected from onion field. Chenopodium album had the highest germination (45.34\%) at $20^{\circ} \mathrm{C}$ followed by $31.91 \%$ at $25^{\circ} \mathrm{C}$. Germination was minimum (16.83\%) at $5^{\circ} \mathrm{C}$ and did not differ significantly from $18.42 \%$ at $10^{\circ} \mathrm{C}$.

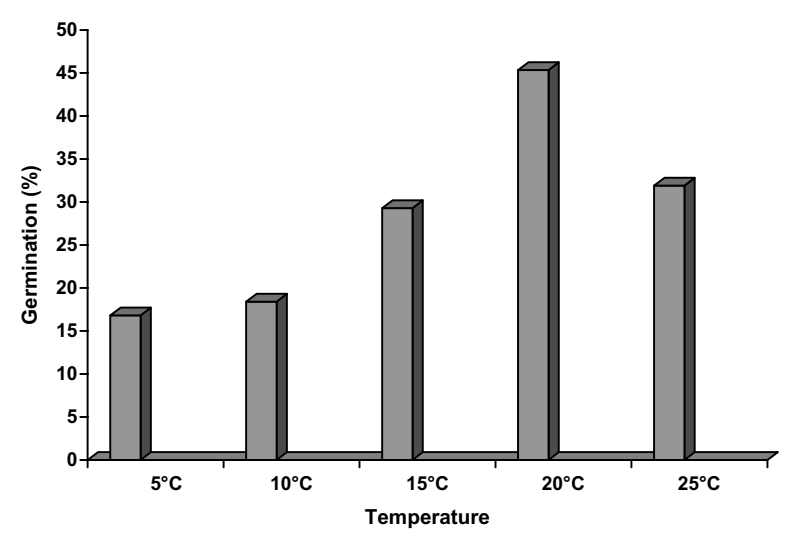

Fig. 1 - Effect of temperature on germination of progeny of C. album seed collected from Onion field.

There was significant variation $(P<0.001)$ amongst germination percentage of $C$. album seed col- lected from the leek field, at different temperatures (Fig. 2). Maximum germination (38.94\%) was recorded at $15^{\circ} \mathrm{C}$, which was statistically on a par with germination $(37.29 \%)$ at $25^{\circ} \mathrm{C}$. Germination of C. album at $25^{\circ} \mathrm{C}$ did not differ significantly from that at $20^{\circ} \mathrm{C}$. The significantly minimum germination $(10.84 \%)$ was recorded at $5^{\circ} \mathrm{C}$.

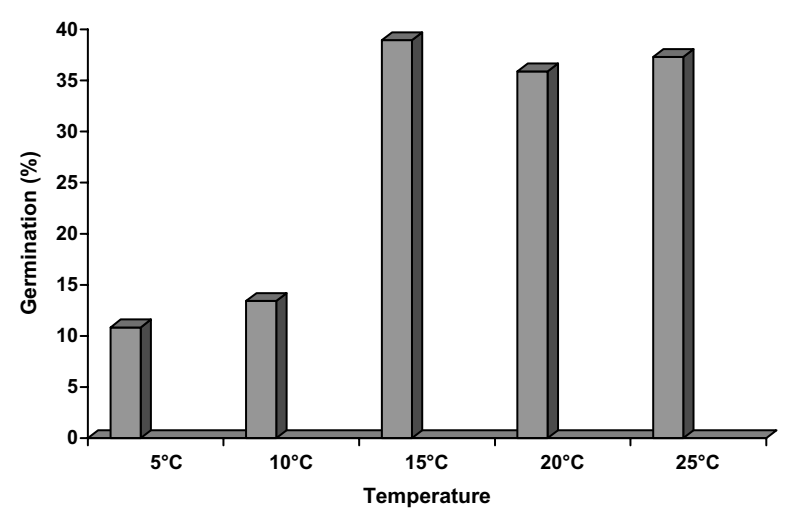

Fig. 2 - Effect of temperature on germination of progeny of C. album seed collected from Leek field.

Germination of C. album seed is very fast at relatively high temperatures, but slows down as the temperature decreases. Low temperatures slowed down germination by increasing the time to onset of germination, reducing the germination rate and lowering the final germination percentage.

\section{Germination of C. album SeEd Collected FROM Plants TREATED With DifFERENT RATES OF HERBICIDES}

Germination of C. album seed collected from the previous onion crop (Table III) sprayed with post-emergence ioxynil and pre-emergence bentazone (each at eighth rate sprayed either once, twice or three times, quarter, half and full recommended rate) did not differ from the unsprayed control (left weedy). However, germination of $C$. album seed was generally higher at higher rates of both herbicides than at lower rates. Germination of C. album seeds from plants treated with herbicides was also higher than the control.

The effect of three pre-emergence herbicides (namely pendimethalin, propachlor and linuron); and post-emergence linuron on percentage germination of C. album seeds collected from the leek field was not significant in comparison with the control (Table IV). 
TABLE III

Effects of pre and post-emergence herbicides on the germination (\%) of the $C$. album seed progeny collected from the onion field.

\begin{tabular}{c|c|c}
\hline \multirow{2}{*}{ Herbicide } & Rate & $\begin{array}{c}\text { Germination } \\
(\%)\end{array}$ \\
\hline \multirow{4}{*}{$\begin{array}{c}\text { Ioxynil } \\
\text { post-em. }\end{array}$} & Eighth & 24.47 \\
\cline { 2 - 3 } & Eighth (twice) & 25.47 \\
\cline { 2 - 3 } & Eighth (3 times) & 27.65 \\
\cline { 2 - 3 } & Quarter & 26.42 \\
\cline { 2 - 3 } & Half & 33 \\
\cline { 2 - 3 } & Full & 30.65 \\
\cline { 2 - 3 } Bentazone & Eighth & 25.78 \\
\cline { 2 - 3 } pre-em. & Eighth (twice) & 29.66 \\
\cline { 2 - 3 } & Quarter & 29.32 \\
\cline { 2 - 3 } & Half & 25.49 \\
\cline { 2 - 3 } & Full & 30.39 \\
\hline \multirow{4}{*}{$\begin{array}{c}\text { Control (weedy check) } \\
\text { SED (df =212) }\end{array}$} & & 23.48 \\
\hline P value & & 2.55 \\
\hline
\end{tabular}

***Significance at the $P \leq 0.001$ level. / NS $=$ not-significant.

Among the pre-emergence herbicides, germination of C. album seeds from plants treated with pendimethalin was generally higher. C. album seeds also showed higher germination when their parent plants were treated with full rate of herbicides compared with half or quarter rate of three pre-emergence herbicides.

Greater germination was recorded from seed where eighth rate of post-emergence linuron was sprayed three times compared with the other rates. This was followed by full rate. Germination of C. album seeds collected from unsprayed plots (control) was higher than that from different rates of pre-emergence propachlor, linuron and post-emergence linuron, but lower than different rates of pendimethalin.

However, whilst trends were observed; the generally non-significant differences in germination of $C$. album seeds indicate that seed germination responded similarly to the different herbicide rates. The results of this experiment seem to follow those of Fawcett and Slife (1978). They found that viability of C. album, Amaranthus retoflexux, Dtaura stramonium and Setaria feberi seeds produced by 2, 4-D and Dalapon treated
TABLE IV

Effects of pre and post-emergence herbicides on the germination (\%) of the $C$. album seed progeny collected from the leek field.

\begin{tabular}{|c|c|c|}
\hline Herbicide & Rate & $\begin{array}{c}\text { Germination } \\
(\%)\end{array}$ \\
\hline \multirow{3}{*}{$\begin{array}{l}\text { Pendimethalin } \\
\text { (pre-em.) }\end{array}$} & Quarter & 30.57 \\
\hline & Half & 33.21 \\
\hline & Full & 37.12 \\
\hline \multirow{3}{*}{$\begin{array}{l}\text { Propachlor } \\
\text { (pre-em.) }\end{array}$} & Quarter & 23.14 \\
\hline & Half & 29.14 \\
\hline & Full & 29.97 \\
\hline \multirow{3}{*}{$\begin{array}{l}\text { Linuron } \\
\text { (pre-em.) }\end{array}$} & Quarter & 21.81 \\
\hline & Half & 20.25 \\
\hline & Full & 25.37 \\
\hline $\operatorname{SED}(\mathrm{df}=252)$ & & 1.83 \\
\hline$P$ value & & NS \\
\hline \multirow{6}{*}{$\begin{array}{l}\text { Linuron } \\
\text { (post-em.) }\end{array}$} & Eighth & 25.01 \\
\hline & Eighth (twice) & 25.18 \\
\hline & Eighth (3 times) & 26.8 \\
\hline & Quarter & 24.59 \\
\hline & Half & 24.19 \\
\hline & Full & 25.54 \\
\hline Control (weedy check) & & 29.72 \\
\hline $\operatorname{SED}(\mathrm{df}=252)$ & & 1.78 \\
\hline $\mathrm{P}$ value & & NS \\
\hline
\end{tabular}

***Significance at the $P \leq 0.001$ level. / NS = not-significant.

plants were not greatly different from control seeds. Similar results were reported by Zollinger and Evans (1985). Non-significant differences in germination percentage indicate that there was no carry-over effect of herbicides sprayed to parent plants on germination of progeny seed in terms of final percentage germination. However, there may be effects on the germination rate that have so far not been analysed. The results of present study are in contrast to those of Biniak and Aldrich (1986), Frank and Ralph (1987), Isaacs et al. (1989), Andersson (1994), Zhang and Cavers (1994) and Shuma et al. (1995), who reported decreased germination of different weed species as a result of herbicides application to parent plants. This contradiction could be attributed to the use of herbicides of different chemical nature, on different weed species at different times, in present and previous study. Clearly generalities cannot be made. 
Finally, we can conclude that the possibility of competition between C. album grown from seeds of herbicides treated parent plants and crop plants is likely to be the same as weeds from seed of untreated plants. This is due to the similar final germination percentages of seeds observed from herbicide treated and untreated plants.

\section{ACKNOWLEDGMENTS}

This study was conducted in the laboratory of School of Science and the Environmental Sciences, Coventry University, Coventry, UK.

\section{RESUMO}

Avaliou-se o efeito residual de doses sub-letais de herbicidas sobre a germinação de sementes de plantas de Chenopodium album sobreviventes em uma cultura prévia de cebola (Allium cepa), que recebeu $2 \mathrm{x}, 3 \mathrm{x}, 1 / 4,1 / 2$ ou a dose recomendada de ioxynil em pré-emergência ou bentazone em pós-emergência. As sementes foram também coletadas de plantas de C. album sobreviventes de um campo de alho-porró (Allium porrum) que havia sido tratado com 1/4,1/2 ou a dose recomendada de pendimethalin, propachlor e linuron em pré-emergência, ou ainda $2 x, 3 x, 1 / 4,1 / 2$ ou a dose recomendada de ioxynil ou linuron em pós-emergência. As sementes destas plantas sobreviventes foram coletadas e testadas quanto à germinação a temperaturas de $5^{\circ} \mathrm{C}, 10^{\circ} \mathrm{C}, 15^{\circ} \mathrm{C}, 20^{\circ} \mathrm{C}$ e $25^{\circ} \mathrm{C}$. Verificou-se que o efeito das temperaturas na germinação destas sementes foi significativa. A germinação foi mínima a baixas temperaturas $\left(5^{\circ} \mathrm{C}\right.$ e $\left.10^{\circ} \mathrm{C}\right)$. Os herbicidas não causaram nenhum efeito na germinação das sementes de C. album tendo resultado no mesmo nível daquelas das plantas controles de culturas não pulverizadas.

Palavras-chave: herbicidas, doses sub-letais, cebola, alhoporró, germinação.

\section{REFERENCES}

ANDERSSON L. 1994. Effects of MCPA and tribenuronmethyl on seed production and seed size of annual weeds. Swed J Agr Res 24: 42-56.

ANDERSSON L. 1996. Characteristics of seeds and seedlings from weeds treated with sublethal herbicide doses. Weed Res 36: 55-64.

BASKIN JM AND BASKIN CC. 1973. Plant population differences in dormancy and germination characteristics of seeds: Heredity or environment: Am Midl Nat 90: 493498.

BASKIN JM AND BASKIN CC. 1977. Role of temperature in the germination ecology of three summer annual weeds. Ocologia (Berl) 30: 377-382.

BAssett IJ AND CROMPTON CW. 1978. The biology of Canadian weeds 32 Chenopodium album L. Can J Plant Sci 58: 1061-1072.

BINIAK BM AND ALDRICH RJ. 1986. Reducing velvetleaf (Abutilon theopbrasti) and giant foxtail (Setaria feberi) seed production with simulated - roller herbicide applications. Weed Sci 34: 256-259.

Catizone P And Viggaiani P. 1990. Aspects of the biology and control of Galium aparine. Proceedings $7^{\text {th }}$ EWRS symposium - integrated weed management in cereals, Helsinki, p. 421-428.

Doliner LH AND Stewart M. 1992. Decision Document E 92-02. Preharvest use of glyphosate. Pesticides directorate, Agri. Canada, Ottawa, Ontario.

DON R, BARTZ J, BRYANTGF M, VAN G, LUNNG, OVERAA $P$ AND STEINER MA. 1990. Germination and tetrazolium testing of treated barley seed samples from glyphosate treated crops in seven IST stations. Seed Sci Technol 18: $175-180$.

FAWCETT RS AND Slife FW. 1978. Effects of 2, 4-D and Dalapon on weed seed production and dormancy. Weed Sci 26: 543-547.

FRANK LY AND RALPH EW. 1987. Efficacy of post harvest herbicides on Russian Thistle (Salsola iberica) control and seed germination. Weed Sci 35: 554-559.

Forcella F, Wilson RG, RenNer KA, DekKer J, Harvey RG, Alm DA, Buhler DD And CARdina J. 1992. Weed seed banks of the US corn belt: magnitude variation, emergence, and application. Weed Sci 40: 636-644.

HALD AB. 1999. Germination of seeds from two non-target species subjected to sublethal herbicide dosages. Proc Brighton Conference - weeds, p. 267-272.

HENSON IE. 1970. The effects of light potassium nitrate and temperature on the germination of Chenopodium album $\mathrm{L}$. Weed Res 10: 27-39.

Henzell R, Phillips J And Diggle P. 1985. Influence of sub-lethal concentrations of herbicides and growth regulators on mouseear cress (Arabidopsis thaliana) progeny. Weed Sci 33: 430-434.

Holm LG, Plucknett DL, Pancho JV and HerberGER JP. 1977. The world's worst weeds: distribution and 
biology. East-West Center/University Press of Hawaii, $609 \mathrm{p}$.

HumE L AND SHIRrifF S. 1989. The effect of 2, 4-D on growth and germination of lamb's quarters (Chenopodium album L.) plants having different degrees of tolerance. Can J Plant Sci 69: 897-902.

ISAACS MA, EDWARd CM, JOE ET AND SUSAN UW. 1989. Effects of late season herbicide applications on sicklepod (Cassia obtusifolia) seed production and viability. Weed Sci 37: 761-765.

KASERA PK AND SEN DN. 1986. Weed seed inviability caused by post-emergence herbicides. Curr Sci 55: 937938.

KintNer D AND ALDRICH RJ. 1984. Effects of post emergence chemicals on velvetleaf (Abutilon theobrasti Medic) seed production and germination. Weed Sci, Soc Am Abstracts, p. 61-62.

OGG AG AND DAwson JH. 1984. Time of emergence of eight weed species. Weed Sci 32: 307-335.
PAyne RW, LANE PW, BAIRd DB, HARING SA AND Morgan GW. 1995. GENSTATS release 3.2. Reference Manual (Supple) Lawes Agricultural Trust (Rothamfted Experimental Station), Harpenden, UK.

Shuma JM, QUick WA, RAJU MVS AND HsiaO AI. 1995. Germination of seeds from plants of Avena fatua L. treated with glyphosate. Weed Res 35: 249-255.

SINGHAL BK AND SEN DN. 1981. A new method of weed control. Curr Sci 50: 414-415.

Young FF, GEALY DR AND Morrow LA. 1984. Effect of herbicides on germination and growth of four weeds. Weed Sci 32: 489-493.

ZHANG J AND CAVERS PB. 1994. Seedling emergence after maternal bentazone application to 10 cocklebur (Xanthium strumarium) populations. Can J Plant Sci 74: 863-866.

ZOLLINGER PK AND EvANS JO. 1985. Effects of chlorsulfuron meiosis and seed viability in rye (Secale cereale $\mathrm{L}$ ). Proc West Soc Weed Sci 38: 114-119. 